\title{
DEMAM INDIA DI INDONESIA
}

\author{
Amalia Irfani, M.Si
}

\begin{abstract}
Abstrak
Industri perfilm-an dunia rasanya kurang lengkap jika tidak dimeriahkan oleh industri film berasal dari india. Walaupun tergolong negara miskin, India mampu menyihir dunia dengan seni peran klasik dan moderen serta seni tari yang begitu eksotik. Sehingga tidak mengherankan disetiap televisi dibelahan dunia, film bollywood menjadi salah satu tontonan terpilih, sangat diminati bahkan ditunggu. Salah satu negara peminat film India adalah Indonesia. Secara historis, ada hubungan yang sangat erat antara India dan Indonesia, mulai dari penyebaran agama, budaya, agama, bahasa dan pendidikan. Tulisannya ini secara singkat akan menggambarkannya hubungan tersebut serta sebab akibat dari televisi.
\end{abstract}

Kata kunci : India, Sejarah, Televisi

\section{A. Pendahuluan}

Setelah beberapa tahun yang lalu industri perfilman asia diramaikan dengan fenomena Korean Pop (K-Pop) termasuk salah satunya di Tanah Air, kini masyarakat kembali dibuat terpana oleh pop culture asal India. Demam India terjadi di Tanah Air dan dialami oleh semua lapisan kalangan usia, status sosial, dan demografis (urban-rural). Setelah sukses tayang serial Mahabrata di ANTV, kini hampir semua stasiun televisi memiliki tayangan film serial
India, seperti Naagin di MNC TV, Aladin di Trans TV, Mahadewa, The Adventures of Hatim, dan Jodha Akbar di ANTV. Bintang-bintang film India pun jadi idola baru seperti: Shaheer Sheikh, Rohit Bhardwaj, Saurav Gurjar, Vin Rana, Lavanya Bhardwaj, Aham Sharma, dan Arpit Ranka. Fenomena ini menandakan babak baru di dunia pertelevisian indonesia, sebagai sebuah negara multitalent, sajian tontonan untuk masyarakat masih terus didominasi oleh negara asing, entah sampai kapan hal ini 
akan terus terjadi, pertanyaan menarik ditengah semakin maraknya perkembangan media informasi.

Melihat fenomena demam India ini, timbul sebuah pertanyaan, ada apa dengan masyarakat Indonesia, mengapa kita sangat menyukai sajian tontonan luar negeri dari pada lokal?. Sekilas munculnya fenomena ini tidak lepas dari preferensi hiburan konsumen kelas menengah. Dengan tingkat pengetahuan dan koneksi sosial yang semakin luas, konsumsi hiburan (entertainment) mereka semakin mengglobal dan modern. Booming K-Pop adalah fenomena gaya hiburan muda. Tidak jauh beda, demam India pun digandrungi oleh di berbagai kalangan usia, tapi lebih banyak perempuan muda. Walaupun bukan "demam perdana", tren India menjadi pemicu muncul tren-tren lain ala India, seperti busana, aksesoris, hingga selera makanan. Berikut ini adalah tiga tren demam India di Indonesia :

\section{Mirip dengan Sinetron}

Serial drama India sangat mirip dengan sinetron yang ada di Indonesia. Adegan yang diperlihatkan, musik yang digunakan tidak jauh berbeda dengan sinetron yang ada di Indonesia. Jalan cerita pun jika dilihat, juga tidak terlalu jauh berbeda.
Bedanya hanya pada aktor-aktrisnya saja.

\section{Dubbing yang Bagus}

Harus kita akui, dubber dalam serialserial drama India sangat baik. Persamaan geografis (kemiripan wajah dan sebagainya), menjadikan dubbing ke dalam bahasa Indonesia tidak terlalu janggal terlihat.

\section{Cerita sejarah dan Dongeng}

Serial seperti Mahabrata, Jodha Akbar bahkan Baalveerr adalah cerita perpaduan antara sejarah dan cerita dongeng. Jika Mahabrata dimodifikasi sesuai tuntutan zaman dan peluang pasar, cerita Jodha Akbar pun demikian, cerita dibumbui oleh dongeng juga imajinasi sutradara dan produser. Sesuai judul cerita jodhaakbar didominasi oleh tokoh Jodha Bhai (Paridhi Sharma) dan Jallaluddin Akbar (Rojat Tokas).

\section{Kostum dan tata Panggung yang Unik}

Kostum merupakan salah satu daya tarik tersendiri dalam sebuah drama. Serial drama India selalu menampilkan kostum unik juga tertata apik. Keunggulan ini yang mungkin menjadi pesona lain film-film produksi India. 


\section{B. Sejarah dan Pengaruh Masuknya Kebudayaan India ke Indonesia}

Pada mulanya hubungan yang terjalin antara Indonesia dengan India adalah hubungan perdagangan. Hubungan ini kemudian berkembang menjadi hubungan agama dan budaya. Proses masuknya pengaruh budaya India ke Indonesia tidaklah berasal dari satu tempat atau daerah di Indonesia. Kita tidak mengetahui secara pasti agama mana yang mula-mula datang ke Indonesia. Tetapi pada masa sekitar permulaan tarikh masehi di Indonesia telah dikenal agama Hindu dan Budha. Pada mulanya agama Hindu yang berkembang dan mempunyai banyak pengikut di Indonesia. Sebenarnya agama Budha juga sudah masuk namun belum berkembang. Hal ini terbukti dari agama yang dipeluk oleh raja Mulawarman dari Kutai dan raja Purnawarman dari Tarumanegara, yakni agama Hindu.

Seorang pengembara Cina bernama Fa-shien menyebutkan bahwa pemeluk agama Budha di Ye-po-ti (Pulau Jawa) tidak banyak. Pada tahun 414 Masehi, Fa-shien datang ke Pulau Jawa karena perahu yang ditumpanginya dari India mengalami kerusakan. Ia kemudian tinggal menetap untuk beberapa waktu di Indonesia. Dia mempelajari kehidupan bangsa
Indonesia ketika itu dan mencatatnya. Disebutkannya bahwa kehidupan pemeluk agama Hindu dan Budha telah dapat hidup berdampingan secara damai. Setelah hidup berdampingan selama berabad-abad terjadilah sinkretisme (perpaduan) antara kedua agama tersebut. Hasil sinkretisme ini kemudian menumbuhkan suatu aliran baru yang disebut Siwa-Budha. Agama ini berkembang pesat pada abad ke-13 Masehi. Penganut aliran agama ini, antara lain raja Kertanegara dan Adityawarman. Meskipun unsur budaya India mempengaruhi budaya Indonesia, tetapi budaya Indonesia tidak kehilangan kepribadiannya. Dalam perkembangannya, pengaruh itu mewujudkan budaya Indonesia baru yang coraknya masih terlihat sampai sekarang. Melalui para pedagang itulah agama dan budaya India disebarkan kepada masyarakat Indonesia. Para pedagang dari India yang beragama Hindu-Budha banyak bermukim di kota-kota pelabuhan. Bahkan, banyak di antaranya yang hidup menetap dan menikah dengan penduduk pribumi. Perkawinan dan permukiman tersebut kemudian mempercepat proses penyebaran agama dan budaya India. Sejak abad ke-7 agama Hindu-Budha mencapai perkembangannya di Indonesia. Berikut beberapa teori 
tentang masuknya kebudayaan Hindu ke Indonesia :

\section{Teori Waisya}

Teori Waisya mengungkapkan masuknya agama dan kebudayaa Hindu dibawa oleh sekelompok pedagang (Waisya). Menurut pendukung teori, kelompok pedagang merupakan kelompok yang berperan besar dalam menyebarkan agama dan kebudayaan Hindu ke Nusantara. Mereka berpendapat pada masa tersebut yang paling banyak berhubungan dengan para penguasa dan rakyat adalah pedagang.

\section{Teori Ksatria}

Menurut teori Ksatria, pembawa agama dan kebudayaan Hindu masuk ke Nusantara adalah kaum ksatria, alasannya pada masa lampau di India terjadi peperangan antar kerajaan. Prajurit yang kalah perang kemudian mengadakan migrasi ke tempat lain. Ada yang sampai ke Indonesia dan mendirikan koloni-koloni melalui penaklukan.

\section{Teori Brahmana}

Teori Brahmana mengungkapkan bahwa pembawa agama dan kebudayaan Hindu sampai ke Indonesia ialah golongan Brahmana. Para Brahmana datang ke Nusantara diundang oleh penguasa Nusantara untuk menobatkan menjadi raja dengan upacara Hindu (abhiseka=penobatan). Selain itu, kaum brahmana juga memimpin upacara-upacara keagamaan dan mengajarkan ilmu pengetahuan.

\section{Teori Nasional Arus Balik}

Teori ini adalah perpaduan dari ketiga teori sebelumnya. Teori Nasional mengungkapkan bahwa penduduk Indonesia banyak yang aktif berdagang ke India. Pulangnya mereka membawa agama dan kebudayaan Hindu. Sebaliknya, orang-orang Indonesia (raja) mengundang brahmana dari India untuk menyebarkan agama dan kebudayaan Hindu di Indonesia, bangsa Indonesialah yang aktif memadukan unsur-unsur kebudayaan Hindu di Indonesia. Menurut teori ini, banyak pemuda Indonesia yang belajar agama Hindu-Budha ke India. Setelah memperoleh ilmu, mereka kembali ke nusantara dan menyebarkankannya.

Berdasarkan keempat teori diatas, pengaruh kebudayaan India dapat ditemui/dilihat sebagai berikut :

\section{Teori Kasta}

Hindu sangat kental dengan sistem Kasta, menurut beberapa sumber sistem 
kasta dan agama Hindu lahir dan berkembang bersamaan. Ketika agama dan kebudayaan Hindu mulai berkembang di Indonesia, sistem kasta tidak berlaku mutlak seperti negara asalnya India. Sistem Kasta dikenal dalam ajaran agama saja, tetapi tidak menerapkannya dalam kehidupan sehari-hari.

\section{Bidang Seni}

Belum ada simpulan akhir dan pasti tentang gaya seni seperti bangunan candi yang ada di Indonesia dengan yang ada di India. Bangunan Candi yang ada di Indonesia bukanlah kebudayaan asli nenek moyang Indonesia, bangunan candi diadaptasi dari kebudayaan India pada masa Hindu-Budha. Perbedaannya, bangunan candi di India berfungsi sebagai tempat pemakaman, sedangkan di Indonesia berfungsi sebagai tempat pemujaan. Jadi, bangsa Indonesia hanya mengambil unsur kebudayaan India sebagai inspirasi dan hasilnya tetap bernuasa lokal Indonesia.

\section{Adanya Konsep Raja dan Kerajaan}

Di Indonesia belum mengenal konsep raja dan kerajaan sebelum kebudayaan India masuk. Indonesia baru mengenal konsep kesukuan dengan wilayah yang terbatas dan dipimpin oleh seorang kepala suku. Kepala suku ini dipilih berdasarkan pada kekuatan fisik dan kekuatan magis yang ia miliki. Setelah kebudayaan India masuk, konsep raja dan kerajaan mulai dikenal, hal ini dapat ditelusuri dari munculnya kerajaan Kutai di Kalimantan Timur.

Menurut para ahli sejarah, Kerajaan Kutai pada mulanya hanya setingkat suku yang dipimpin oleh kepala suku yang disebut Kudungga. Kutai mulai kelihatan menjadi sebuah kerajaan sejak pemerintahan Raja Aswawarman.

\section{Demam India di Indonesia}

Secara singkat, dari uraian-uraian diatas secara historis kedekatan Indonesia dengan India bukanlah hal yang baru. Tahun 1980-1990-an India sempat merajai perfilman, bersaing ketat dengan film-film produksi Amerika dan Eropa. Sebelumnya melalui film-film layar lebar di tahun 1996-1997, India "membahana" melalui film Kuch-kuch ho ta hai, yang dibintangi oleh King of Bollywood Shahrukh Khan (SRK) dan Kajol. Debut dari Karan Johar tersebut, membuat India lebih berani menampilkan diri. Mereka mulai membuat karya-karya fenomenal yang disukai pasar lokal dan dunia. Jika film-film tidak lagi berjaya karena kurang diminati dengan alasan zaman dan penonton yang berubah 
selera, India membuat karya baru dan masih mampu menyaingi Hollywood, dan drama bersambung (sinetron) mereka sungguhkan.

Berikut ini beberapa ciri khas film India dekade 1980-1990an :

1. Nyanyian, dimana para aktor dan aktris juga menyanyi (apakah lipsync atau tidak)

2. Tarian, dimana setiap film India pasti ada tarian yang menghibur.

3. Tangisan, dimana selalu ada kesedihan yang terjadi pada film tersebut.

4. Inspektur Vijay, yang merupakan pimpinan Kepolisian, yang kadangkala bersifat tidak baik, hal ini menunjukkan bahwa Polisi tidak selalu kelihatan baik (tidak seperti di Indonesia, Polisi kalau di film selalu kelihatan baik, tetapi kenyataannya belum tentu).

5. Percintaan/asmara, antara seorang wanita dan pria yang kadangkala selalu mendapatkan pertentangan apakah dari keluarga atau dari orang lain.

6. Perkelahian, dimana hampir selalu terjadi di setiap film India.

Ciri-ciri khas diatas dengan era 2000-an tidak terlalu berbeda, tampilan Film-film produksi India masih mengedepankan aksi-aksi laga berdarah, kisah-kisah cinta nan romantis.
Perbedaan mungkin hanya pada ide-ide cerita yang lebih inovatif, animasi pun menjadi ciri lain dari film-film India era 2000-an. Berikut berapa film-film India yang booming di Indonesia ditayangkan di ANTV ${ }^{1}$ :

${ }^{1}$ ANTV didirikan pada 1 Januari 1993 sebagai stasiun televisi lokal di kota Lampung. Tanggal 18 Januari 1993 antv mendapat izin siaran nasional melalui Keputusan Menteri Penerangan RI No. 04A/1993. Sepuluh hari setelah izin tersebut keluar, antv mengudara secara nasional. Meski resmi mengudara secara nasionalnya dilakukan pada Februari 1994, dengan memperluas jaringan berikut menambah jam siaran menjadi 18 jam sehari. Studio antv yang semula berada di Lampung dipindahkan secara bertahap keJakarta.

Tepat tanggal 1 Maret 1993 antv untuk pertama kalinya memproduksi program sendiri berupa liputan berita aktual jalannya Sidang Umum DPR/MPR. Saat itu antv berhasil melakukan siaran langsung meliput jalannya kegiatan penting kenegaraan. Momen istimewa itu yang kini dijadikan sebagai pembentukan SMS Entertainment, pada 1 September 2003.

Stasiun televisi ini pada mulanya dikhususkan pada pemirsa remaja (usia 13-25 tahun) dan pernah menyiarkan acara-acara MTV Indonesia hingga awal tahun 2000-an, tetapi tahun 2002 stasiun ini berkembang menjadi stasiun untuk segala usia, sama dengan stasiun televisi yang lain.

antv berhasil mencatatkan prestasi gemilang di Museum Rekor Indonesia (MURI) sebagai penyelenggara konser selama 5 jam yang diselenggarakan awal tahun 2001.

Pada 30 April 2006 antv berhasil menjalin kerjasama strategis dengan jaringan televisi dunia STAR TV. Kerjasama ini ditandai dengan masuknya 20\% saham antv ke STAR TV. Hal ini sesuai dengan ketentuan yang berlaku.

Saat ini, antv dimiliki oleh PT Visi Media Asia Tbk (melalui PT Intermedia Capital Tbk). 


\section{Mahabharata}

Durasi serial ini hanya 20 menit, tetapi tidak membuat Mahabrata sepi penonton, sebaliknya membuat penonton menjadi makin penasaran dan selalu menunggu kelanjutannya. Mahabrata juga menjadi serial televisi fenomenal dan termahal di dunia dengan ongkos produksi Rp. 199 miliar, dan kru produksi sebanyak 600 orang.

Sinopsis Mahabharata berfokus pada perebutan tahta Kerajaan Hastinapura. 100 Kurawa dan 5 Pandawa adalah dua kelompok keluarga yang memiliki latar belakang berbeda namun sama-sama berebut untuk mendapatkan tahta Hastinapura. Puncak dari perebutan tahta antara Pandawa dan Kurawa adalah terjadinya Perang Kurukshetra atau yang di Indonesia lebih dikenal sebagai Perang Baratayuda. Perang yang terjadi selama 18 hari ini juga menjadi klimaks dari kisah Mahabharata.

\section{Mahadewa}

Serial Film India Mahadewa pertama kali tayang pada 18 Desember 2011 di Star Vijay TV India. Sama seperti Serial Mahabharata, serial Mahadewa juga mempunyai durasi yang pendek per episodenya. Rata-rata per episodenya hanya tayang sekitar 20 menit saja, tetapi kemasan yang apik mampu membuat Mahadewa menjadi tontonan favorit.

Jalan Cerita Serial Mahadewa akan berfokus pada kisah percintaan Dewa Shiwa dengan Dewi Shakti. Dewa Shiwa sendiri merupakan dewa yang paling kuat dalam budaya Hindu. Serial ini mengisahkan bagaimana pertemuan awal mereka dan bagaimana kisah cinta mereka dalam membentuk dunia. Akan ada banyak pertentangan dan konflik sebelum mereka akhirnya bisa bersatu.

\section{Ramayana}

Ramayana merupakan salah satu serial favorit yang selalu ditunggu oleh masyarakat dunia, tidak terkecuali di Indonesia. Film yang berkisah tentang kisah cinta Rama dan Shinta ini memang sungguh menghadirkan drama cinta yang romantis. Sinopsis Serial Ramayana Di ANTV diawali dengan adanya seseorang bernama Rama, yaitu putra Mahkota Prabu Dasarata di Kosala dengan ibukotanya Ayodya. Tiga saudara tirinya bernama Barata, Laksmana dan Satrukna.Rama lahir dari isteri pertama Dasarata bernama Kausala, Barata dari isteri keduanya bernama Kaikeyi serta Laksmana dan Satrukna dari isterinya ketiga bernama Sumitra. Mereka hidup rukun. Dalam 
kisah ini ada cerita tentang romansa Sri Rama dan Shinta serta pertarungan antara Rama dengan Rahwana yang seru.

\section{Jodha Akbar}

Cerita Jodha Akbar merupakan serial India yang berfokus pada kisah cinta di zaman abad ke-16. Jodha Bai (Paridhi Sharma), putri dari kerajaan Rajhput terpaksa dinikahkan dengan Jallaludin Mohammad Akbar (Rajat Tokas) yang merupakan raja dari Mughal. Perkawinan politik ini terjadi untuk manyatukan dua kerajaan tersebut agar semakin kuat di abad itu. Akbar sendiri sudah mewarisi haknya sebagai Raja Mughal sejak berusia 13 tahum, setelah kematian sang ayah.

Awalnya pernikahan Akbar dan Jodha ini hanya dilangsungkan karena alasan pernikahan politik saja. Akbar ingin menguasai wilayah kekuasaan dari kerajaan Jodha. Namun siapa sangka jika ternyata awal yang tidak manis ini benar-benar mengubah hati keduanya yang kemudian saling terpaut satu sama lain walau berbagai lika-liku menghadang mereka berdua. Ini juga merupakan kisah sejarah awal mula berdirinya Taj Mahal India.

Selain Jodha Akbar, kisah menarik lain juga ditawarkan ANTV dengan serial berjudul Mahaputra. Secara singkat serial Mahaputra ini adalah, drama sejarah yang mangangkat kisah kepahlawanan India yang patriotik dari Rajashtanm Maharana Pratap. Maharana Pratap adalah raja yang sangat berani dan kuat, yang memerintah kerajaan Mewar pada abad ke-16. Kisah kepahlawanannya ini saat ia mengangkat pedang melawan Afgan, Mughal dan Turki yang ingin menguasai kerajaannya.

\section{The Advent ures Of Hatim}

Sinopsis The Adventures Of Hatim yang dibintangi Oleh Rajbeer Singh dan Pooja Banerjee ini Bercerita tentang seorang pria biasa bernama Hatim (diperankan oleh Rajbeer Singh) yang terpilih untuk menyelamatkan orangorang dari kekuatan jahat, dan nantinya Hatim akan berjuang untuk menghancurkan kekuatan Zargam Sang penyihir jahat. Cerita ini merupakan salah satu fiksi yang mendapat pujian karena jalan ceritanya yang menarik, sama seperti serial Baalveer, dongeng untuk anak ini dikemas apik dengan memadukan unsur fiksi dan unsur lokal yakni kesenangan anak-anak terhadap tokoh idola seperti Spiderman, atau Hulk. 


\section{Hubungan Televisi, Film (Serial), dan Masyarakat}

Televisi adalah gambar yang paling kompleks pada media ruparungu dwimatra 5 dinamis (moving audiovisual media), bahasa rupa inilah yang dianggap paling pesat perkembangannya. Temuan Yayasan Kesejahteraan Anak Indonesia tahun 1996 yang dilansir majalah [aikon!] media alternatif menyebutkan bahwa kekuatan besar televisi yang tidak pernah dibayangkan oleh Paul Nipkow sekalipun ketika dia mematenkan Jantra Nipkow yang menjadi cikal-bakal televisi mekanis; temuan itu memaparkan bahwa anakanak Indonesia (usia 6-15 tahun) "harus menyisihkan" waktu 22-26 jam per minggu untuk menonton televisi. Bahkan anak Amerika sejak usia delapan belas bulan sudah secara mendalam dikonfrontasikan pada medium televisi. Pada akhir humaniora-nya jumlah jam menonton televisi dari anak-anak muda Amerika mencapai 16.000 jam. Ketika usia mencapai 20 tahun secara total hampir mencapai juta reclamesport atau mencapai rata-rata 1000 per pekan (Tondowidjojo 1999:57).

Televisi mengkomunikasikan pesan - pesannya dengan cara yang sangat sederhana. Sifat televisi yang demikian, disebut sebagai penyampaian pesan sepintas atau transitory. Karena itulah maka pesanpun harus mudah dipahami dalam sekilas dan dengan jenjang konsentrasi yang tidak setinggi membaca. Pesan-pesan yang harus bersifat begitu sederhana itu, dengan idiom-idiom gambar yang sanga $t$ universal sehingga tayangan untuk orang dewasa pun dengan dipahami anakanak. Pesan-pesan yang disampaikan secara audio (bahasa tutur) berentang kosakata sangat terbatas menyebabkan interaksi televisi dengan pemirsa dianggap selesai segera setelah informasi lewat tanpa dapat direvisi, diverifikasi apalagi dievaluasi.

Menurut Garin Nugroho pertelevisian Indonesia tidak pernah bisa dilepaskan dari alat kekuasaan, la menuturkan : Televisi Indonesia adalah sejarah propaganda sekaligus penerangan selama lebih kurang 30 tahun. TVRI adalah jabang bayi politik mercu suar Asian Games (tahun 1967). Kemudian di masa Orde Baru, TVRI adalah sejarah penerangan dan ketika swastanisasi lahir pada tahun 1990-an, televisi adalah medium hiburan dan informasi. Namun tetap dalam perspektif mendukung dan tidak mengganggu kekuasaan Orde Baru. Dengan kata lain, sejarah tigapuluh tahun televisi Indonesia adalah sejarah penggunaan televisi untuk penegakan kekuasaan. 
Dalam kajian ilmu ada hubungan yang erat antara film dan masyarakat. Film sebagai alat komunikasi kedua yang muncul di dunia, mempunyai masa pertumbuhan pada akhir ke-19. Berkembangnya film, berkembang pula televisi yang dapat dibuktikan dengan film mampu mengambil alih penonton, dan kebanyakan berusia muda. Seiring dengan beralihnya penonton film menjadi penonton televisi, film mengalami integrasi besar-besaran dengan media lainnya, terutama dengan penerbit buku, musik populer dan bahkan dengan televisi sendiri. Dewasa ini film berperan sebagai pembentuk budaya massa, beriringan dengan kemajuan internet melalui media-media sosialitanya.

Televisi dan film seperti serialserial bersambung mempunyai dampak tertentu bagi penontonnya. Dalam banyak penelitian tentang dampak serial televisi dan film terhadap masyarakat, hubungannya dipahami secara linier; yakni apa yang ditayangkan televisi selalu mempengaruhi dan membentuk masyarakat berdasarkan muatan pesan dibaliknya, tanpa pernah berlaku sebaliknya. Keunggulan lain dari film adalah kekuatan dari film menjangkau banyak segmen sosial, film menjadi lebih bebas untuk memenuhi kebutuhan akan sajian yang berbau kekerasan, mengerikan dan pornografis (McQuail, $1987: 15)$.

Serial televisi juga dipercaya sangat efisien dalam menyebarkan gagasan dan dalam menanamkan perilaku. Serial-serial bersambung produksi India yang ditayangkan di televisi swasta di Indonesia sedikit banyak telah menanamkan perilaku bersifat langsung maupun tidak langsung. Perilaku-perilaku tersebut dapat dilihat dari tingkah laku keseharian masyarakat. Anak-anak misalnya kesukaan pada serial Baalveer membuat mereka jadi lebih agresif dengan meniru orang dewasa. Anak-anak penonton Baalveer melihat seorang model melakukan kekerasan memukul, menendang, berkata-kata kasar dan bersikap tidak baik dengan sesamanya, seperti : berbohong, berkelahi, atau bermusuhan. Menurut Bailey (1988 : 45), peniruan maupun pembiasaan dimulai dari rumah, tetapi banyak dipengaruhi oleh dunia luar yang lebih luas, baik oleh sekolah, tradisi nasional dan agama maupun oleh buku, majalah, surat kabar terutama film dan televisi.

Berikut pengaruh Positif Televisi yang dapat diidentifikasi :

1. Dalam hal penyajian berita, televisi umumnya selalu up to date, mampu menyajikan berita terbaru langsung dari lokasi kejadian. Hal ini tentu akan 
membuat Anda tidak ketinggalan informasi dan memberikan wawasan yang cukup luas pada Anda secara cepat.

2. Bila televisi menyajikan acara - acara yang berhubungan dengan pendidikan, hal ini tentu sangat berguna bagi para pelajar. Seorang pelajar bisa mengambil manfaat berupa informasi pendidikan dari acara televisi tersebut.

3. Tayangan televisi mampu menyegarkan otak dengan menonton beragam tayangan hiburan yang disajikan oleh stasiun televisi. Mulai dari acara kuis, film, sinetron, atau hiburan-hiburan yang lain.

4. Televisi banyak menampilkan tokohtokoh yang memiliki pengaruh, baik dalam dunia pendidikan, dunia usaha, hiburan, atau yang lainnya. Figur-figur yang ditampilkan dalam televisi ini bisa memicu Anda untuk mencontoh kesuksesan mereka.

Selain dampak positif, berikut dampak negatif dari televisi seperti :

\section{Pembodohan kaum muslimin}

Diantara dampak negatif akibat dari kemajuan sains dan teknologi adalah banyaknya kaum muslimin yang bodoh dan dibodohkan terhadap perbedaan dan kesamaan dengan kaum
Nashrani dalam satu sisi, dan kurang begitu sadar terhadap gelombang pemikiran sesaat dan gaya hedonisme dalam sisi lain, hingga sekelompok mereka mencoba mengadopsi sistem dan ideologi kuffar dalam semua bidang. Bahkan sebagian mereka dengan tegas menolak atau alergi dengan segala hal yang berbau Islam dan nilai moral karena terpengaruh dan silau oleh kemajuan teknologi dan keunggulan materi para penentang Islam yang hanya menjanjikan "kesuksesan" sementara.

\section{Media penebar maksiat dan pengusung laknat}

Televisi lebih berbahaya daripada para perampok yang mungkin hanya menjarah harta dan melukai jiwa mereka, sementara TV disamping menguras harta benda yang lebih kejam lagi acara TV, merampok kehormatan dan merampas kesucian serta menghancurkan moral keluarga. Namun hanya sedikit diantara kita yang sadar akan dampak dan bahaya yang ditimbulkan TV, sehingga tanpa merasa berdosa maupun menyesal mereka menghabiskan waktunya di depan TV.

\section{Pergeseran nilai tontonan menjadi tuntunan}

Produk per-televisian yang paling laris dan banyak menyedot pemirsa 
adalah sinetron religi yang secara umum banyak memunculkan berbagai kontroversi di dalam masyarakat. Hal ini dikarenakan sinetron religi banyak mengandung pelanggaran terhadap syariat, norma dan moral agama. Bahkan, ia menggeser habis-secara perlahan-peradaban bangsa dan karakter umat. Sehingga tuntunan agama menjadi tontonan dan tontonan menjadi tuntunan atau pengganti ajaran agama. Bahkan, keyakinan mereka terhadap akhirat rusak karena terpengaruh oleh sinetron.

\section{Televisi melumpuhkan kemampuan berpikir kritis}

Dharma Singh Khalsa, penulis buku "Brain Longevity" adalah seorang dokter yang membuka praktik latihan mental untuk memelihara usia otak. la pernah menceritakan bahaya menonton TV dalam hubungannya dengan kesehatan otak. TV menjadikan otak pasif, melumpuhkan kemampuan berpikir kritis dan merusak terutama sekali kecerdasan spacial pada otak sebelah kanan. Tetapi bahaya yang paling besar dari TV ialah mengalihkan perhatian orang dari membaca. Efek TV lainnya yang menakutkan dan juga efek kesibukan kita yang sibuk, ialah sekarang ini terlalu sedikit orang yang punya waktu untuk membaca. Membaca, menurut peneliti neurologis sangat menguntungkan otak. Tentu saja banyak bahan bacaan yang memperkaya secara intelektual, tetapi semata-mata membaca saja, tidak jadi soal apa isinya, sangat bermanfaat. Membaca memerlukan keterlibatan aktif pikiran dan imajinasi. Membaca sangat merangsang kedua belahan otak dan juga sistem limbik.

\section{Benih kekerasan "Smackdown"}

Perkelahian yang tampil di "smackdown" adalah pekelahian purapura yang direkayasa. Namun yang tampil di layar sangat realistis. Disinilah masalah muncul. Apakah hasil rekayasa atau sungguhan, apa yang muncul di layar, yang dilihat oleh penonton, dianggap sesuatu yang realistis oleh penonton dan ini bisa menimbulkan dampak bagi penonton, yakni merangsang agresivitas penonton. Terutama bagi anak-anak dan remaja yang belum kritis menggunakan media, tayangan semacam ini berpotensi untuk membuatnya meniru aksi-aksi kekerasan yang dilihatnya di layar.

\section{Globalisasi pornoaksi di Televisi}

Inilah lagi bukti betapa hukum memang susah betul ditegakkan di negeri ini. TV menampilkan adegan cabul! Adakah sanksi untuk penayangan 
yang dapat berakibat buruk di masyarakat ini? Tidak. Stasiun TV-nya hanya minta maaf! Persoalan pun selesai. Yang disayangkan pula KPIPusat (Komisi Penyiaran IndonesiaPusat) hanya menegur dan tidak melakukan upaya lebih jauh dalam menindak pelanggaran-pelanggaran yang ada. Hal ini menakutkan, karena kepada siapakah sebenarnya masyarakat harus berharap untuk melindungi dirinya dari dampak pornografi? Beban untuk memikirkan ini tampaknya masih ada pada masyarakat penonton yang harus pintar-pintar memilih isi siaran yang aman untuk keluarga.

\section{Melemahkan kognitif anak-anak}

perkembangan

Televisi sebagai baby-sitter tampaknya tidak masalah. Namun berbagai penelitian dan berbagai fakta menyebutkan "meletakkan" anak-anak apalagi dalam usia dini sangat berbahaya baik dari fisik maupun psikis. Apalagi dalam waktu yang panjang, bisa mencapai 6-jam sehari. Bagi anak-anak di bawah 3 tahun, menonton TV terlalu dini bisa mengakibatkan proses wiring penyambungan antara sel-sel syaraf dalam otak - menjadi tidak sempurna. Pada anak-anak yang lebih besar, berpengaruh pada kelambanan berbicara. Ini terjadi karena aktivitas menonton TV tidak menggugah anak untuk berpikir. Apa yang disajikan TV sudah lengkap dengan gambar dan suara. Sudah banyak penelitian menyebutkan, semakin sering anak mengkonsumsi TV, semakin sama nilai yang dianutnya dengan tayangantayangan dari TV.

\section{Mesin penggerak identifikasi remaja}

TV menyodorkan berbagai acara untuk menciptakan ketergantungan pada remaja, sehingga remaja Indonesia khususnya- cenderung dipaksa bukan menjadi dirinya melainkan menjadi menurut kehendak kepentingan TV. Hal ini menjadikan remaja menjadi pribadipribadi yang lentur, tidak mempunyai pengalaman empirik untuk meletakkan empati sosialnya. Kenyataan sosial disekitarnya telah dikompres oleh media TV dengan mereduksi kekayaan kemungkinan dan nilai yang terkandungnya. Demikian pula dalam pola pembentukan tipe idealitas, TV bisa menjadi pelaku atau sekedar agen perantara bagi munculnya konsepkonsep tertentu. Antara lain, perempuan yang cantik adalah perempuan yang berkulit putih, berambut panjang, lurus, dan sebagainya. 


\section{Menghapus jati-diri seorang ibu}

Dalam konsep keluarga di Indonesia, kaum ibu adalah kalangan yang paling memiliki ketergantungan pada media TV. Karena posisinya ini pula, kaum ibu mempunyai tingkat ketergantungan yang tinggi. Lihat saja, acara-acara pada jam ibu rumah tangga yang ada di rumah. Di ragam dan jenis iklan-iklan yang ditayangkan sudah biasa diketahui siapa yang menjadi sasarannya. Hampir seharian, seorang ibu bisa menghabiskan waktunya di depan TV. Dengan karakter dan strategi program atas pengenalan audiens-nya, pengaruh yang diharapkan pada kalangan kaum ibu adalah menjadi konsumen, pelanggan dari semua agenda dan kepentingan yang ditawarkan di dalamnya dan bila sudah tercapai maka harus dibuat agar muncul ketergantungan di dalamnya. Kaum ibu bisa menjadi orang yang kehilangan jatidirinya, kehilangan ke-percayaan-dirinya, dan rela di ombang-ambingkan oleh situasi di sekitarnya. Dalam kata-kata rayuan, alangkah mudahnya menjadi ibu modern, ibu yang bijak atau ibu yang ,mengetahui keluarganya. Ibu baik dalam konstruk masyarakat dikompres dalam pengertian verbal.

\section{Fisik dan mental jadi terganggu}

Secara fisik, terlalu banyak menonton TV juga akan mengganggu gerakan otot mata anak. Mata terbiasa melihat lurus dan tidak bisa bergerakgerak seperti saat membaca buku. Selain mengganggu otot mata, menonton juga mengakibatkan metabolisme tubuh terganggu karena anak cenderung pasif, tidak banyak bergerak. Karena itu, anakanak yang banyak menghabiskan waktu dengan menonton TV punya kecenderungan mengalami kegemukan. Dari sisi kejiwaaan, iklan dan tayangan yang ditonton anak bisa mendorong anak menjadi konsumtif. Anak yang senang pada satu tayangan, jadi tertarik memiliki produk tokoh tayangan atau bahkan segala produk yang diiklankan oleh tokoh favorit mereka. Belum lagi kalau bicara soal tindak kekerasan yang banyak diumbar diberbagai tayangan anak. Tak heran bila berbagai penelitian lain lantas menunjukkan bahwa anak-anak yang banyak menonoton TV cenderung lebih agresif dibandingkan dengan anak yang jarang menonton TV. Ini belum termasuk banyaknya kalimat-kalimat negatif seperti makian dan ejekan yang dilontarkan tokoh TV.

Dampak buruk tayangan TV memang tidak terlihat segera pada diri anak. Efeknya bisa jadi baru terlihat 
belasan tahun mendatang. Kekerapan menonton adegan kekerasan dalam TV akan menimbulkan dampak kumulatif yaitu anak-anak menjadi tidak peka terhadap kenyataan dan konsekuensi kekerasan. Bahkan, mungkin lebih cenderung menganggap kekerasan merupakan solusi dari persoalan kehidupan sehari-hari. Efek buruk lainnya adalah efek "candu". Bila sudah nyandu, anak akan menganggap tidak ada kegiatan lain yang lebih asyik dibandingkan menonton TV. Lebih parah lagi, bila efek ini mengakibatkan anak jadi malas bersosialisasi dengan orang lain.

\section{Dangkalnya mekanisme kerja TV}

Serba medium adalah fakta lain dari serba dangkal karena sistem dan mekanisme kerja media TV tidak mampu (dan tidak mau) berjalan seiring dengan tingkat akselerasi sosial masyarakatnya. Mekanisme kerja TV tidak memberikan kemungkinan munculnya kedalaman. Para praktisi media TV tidak memiliki kesadaran profesional bahwa efek mediasai yang dilakukan bisa berpengaruh luas pada masyarakat. Tayangan yang semula dalam konsep dan prasangkanya dipercaya untuk mereduksi (menekan, mengurangi) justru menjadi reproduksi (melipatgandakan).
Pada sisi lain, masyarakat, dibimbing oleh teror media, merasa memiliki dalil pembenar karena apa yang dilakukan bukanlah sesuatu yang sendirian. Banyak orang melakukannya. Sementara bagi pihak TV, adanya aturan etis, dengan sanksi moral, bukanlah hal yang menakutkan. Kenapa? Karena aspek moralitas bukan faktor penting bagi praktisi media di Indonesia, atau jika tidak, memang tidak ada moral disitu.

\section{Pembentukan masyarakat konsumsi}

Kecenderungan "menggantung" masyarakat dikarenakan oleh karakter TV yang serba cepat dan serba baru. Kehidupan masyarakat akhirnya di daulat oleh pasar yang hendak diciptakan, dengan media sebagai perantaranya. Dalam korelasi ini, masyarakat digantung menjadi masyarakat konsumsi. Masyarakat konsumsi adalah jenis masyarakat yang hanya berposisi sebagai "pembeli" bukan "pembuat". Pembeli hanyalah objek, target sasaran. Dia ditentukan dan bukan menentukan. Apa buruknya masyarakat konsumsi? Bahaya terbesar dari hal itu adalah munculnya masyarakat yang tidak memiliki karakter kemandirian. Ketika tidak ada lagi yang bisa diolahnya untuk menopang daya konsumsinya, maka yang terjadi adalah ketergantungan dan 
anomali. Masyarakat seperti ini adalah masyarakat yang tidak memiliki ketahanan budaya, tanpa identitas, masyarakat komunal dan beragam. la tidak mengenali lingkungannya karena hidup dianggap berpusat pada dirinya, memburu kesenangan pribadi dan mempersetankan kitaran.

\section{Persaingan kepentingan modal dan moral}

Ketika media massa, seperti TV, tunduk pada kepentingan modal, maka kepentingan moral untuk masyarakat bisa menjadi ambivalen. Yang ia lihat, masyarakat adalah sederet rating. Dari situasi masyarakat yang semacam ini, tidak ada yang bisa diharapkan apa-apa untuk melakukan perubahan, kecuali ketertenggelaman menanti. la bisa lebih dahsyat dari tsunami karena perlahan menenggelamkan dunia ini dengan manusianya sekaligus. Masyarakat perlu membentengi dirinya sendiri, untuk berani mematikan TV, begitu acara itu tidak bermanfaat secara langsung pada dirinya : bahwa semuanya itu adalah realitas media TV, realitas simbolistik, dan itu beda dengan keseharian kita.

Orang yang menonton televisi secara terus-menerus umumnya akan menjadi pemalas karena badannya tidak banyak bergerak. Biasanya hanya duduk diam atau tidur-tiduran di depan televisi.
Kalau selalu dalam posisi seperti itu setiap hari dalam waktu lama, tubuh tidak akan terbiasa bekerja berat, akibatnya adalah tubuh menjadi lemah dan lemas ${ }^{2}$

Untuk menanggulangi atau meminimalisir pengaruh negatif televisi, beberapa hal yang bisa dilakukan adalah sebagai berikut :

1. Sebagai orang tua, hendaknya kita mengingatkan kepada anak kita agar melakukan tugas utamanya yaitu belajar. Jangan sampai karena menonton televisi anak menjadi lupa akan waktu belajarnya.

2. Sebagai orang tua, hendaknya kita ikut membimbing anak dalam menonton tayangan televisi agar perilaku anak nantinya tidak konsumtif gara-gara menyaksikan beragam iklan yang menarik.

2 Untuk menanggulangi atau meminimalisir pengaruh negatif televisi, beberapa hal yang bisa dilakukan adalah sebagai berikut :

- Sebagai orang tua, hendaknya kita mengingatkan kepada anak kita agar melakukan tugas utamanya yaitu belajar. Jangan sampai karena menonton televisi anak menjadi lupa akan waktu belajarnya.

- Sebagai orang tua, hendaknya kita ikut membimbing anak dalam menonton tayangan televisi agar perilaku anak nantinya tidak konsumtif gara-gara menyaksikan beragam iklan yang menarik.

- Sebagai orang tua, hendaknya kita memilih program televisi kepada anak yang mendidik, bukan yang menjerumuskan. Hal yang perlu di ingat kembali adalah berikan pengawasan terhadap anak. 
3. Sebagai orang tua, hendaknya kita memilih program televisi kepada anak yang mendidik, bukan yang menjerumuskan. Hal yang perlu di ingat kembali adalah berikan pengawasan terhadap anak.

\section{E. Kesimpulan}

Demam India di Indonesia bukanlah hal baru terjadi. Sebelumnya India melalui film-film layar lebarnya wara-wiri di televisi Indonesia tahun 1980-1990-an. Sejatinya, bukan kali pertama produk hiburan India masuk Indonesia. Di tahun 90-an dulu TPI (kini MNCTV) rutin menayangkan serial India seperti Ramayana dan Mahabharata (versi 80-an) serta film layar lebar India. RCTI dan SCTV ikut menayangkan film India, pada slot daytime. Di tahun 1998, Indosiar menggebrak lewat penayangan film India di waktu primetime, Mega Bollywood. Judul pertama yang tayang, Kuch Kuch Hota Hai, meraih rating tinggi. Tidak perlu menunggu lama SCTV pun membuat slot Gala Bollywood dan RCTI dengan Layar Emas Bollywood, yang juga tayang primetime. Tren ini kemudian memudar di era 2000-an. Produk lokal, kembali merajai layar kaca Indonesia. Kalau pun ada tayangan impor yang diterima pemirsa TV, umumnya berasal dari Asia Timur (Taiwan dan Korea
Selatan). Dibandingkan televisi swasta lain di Indonesia, Hanya MNCTV yang terbilang rutin menayangkan film Bollywood, meski sebagian besar sudah pernah diputar puluhan kali. Demam India kembali terasa ketika ANTV menayangkan serial Mahabharata di slot primetime. Sejak awal penayangan, serial ini stabil di urutan 10 besar, bahkan 5 besar-dan jelang berakhirnya sulit sekali dilengserkan dari peringkat 1 , bahkan kini Mahabrata ditayangkan ulang atas permintaan pemirsa.

Persamaan budaya menjadi faktor penyebab mengapa serial-serial dari India sangat diminati oleh masyarakat Indonesia, selain karena dubbing bahasa yang pas; penjiwaan dubber juga menjadi faktor penentu yang membuat serial India favorit dan sangat diminati. Fenomena ini diperkirakan akan bertahan selama kurang lebih 3 (tiga) hingga 5 (lima) tahun kedepan. Seperti serial-serial impor lainnya, India masih akan tetap diminati masyarakat Indonesia, hanya volumenya saja yang sedikit berkurang.

\section{F. Daftar Pustaka}

Bustanuddin, Agus. 2005. Agama Dalam Kehidupan Manusia. Jakarta : PT. RajaGrafindo Persada

Stanley J Baran, Dennis K Davis. Teori Dasar Komunikasi Pergolakan, 
dan Masa Depan Massa, Jakarta : Penerbit Salemba Humanika www. Indiamovie.com Masduki. 2007. Regulasi Penyiaran dari Otoriter ke Liberal. Yogyakarta : LkiS
Hidajanto Djamal. 2011. Dasar-dasar Penyiaran. Jakarta : Prenada Media Group 